\title{
Bilateral extraocular muscle (EOM) metastases from adenocarcinoma of the gastro-oesophageal junction (GOJ)
}

\author{
Maximilian Julve, ${ }^{1}$ Mufudzi Maviki, ${ }^{2}$ Roopinder Gillmore ${ }^{1}$
}

Department of Oncology, Royal Free London NHS Foundation Trust, London, UK ${ }^{2}$ Department of Radiology, Royal Free London NHS Trust, London, UK

Correspondence to Dr Roopinder Gillmore, r.gillmore@nhs.net

Accepted 23 July 2014

\section{$\underset{\infty}{ }$ CrossMark}

To cite: Julve M, Maviki $M$, Gillmore R. BMJ Case Rep Published online: [please include Day Month Year] doi:10.1136/bcr-2014205368

\section{DESCRIPTION}

A 77-year-old man with known adenocarcinoma of the gastro-oesophageal junction presented with symptoms of general deterioration associated with right-sided retro-orbital pain and visual disturbance. The visual acuity in the right eye was normal but there was paralysis of the lateral gaze. Furthermore, the left eye was deviated medially and inferiorly and there was very little preserved coordinated movement.

Twenty months prior to this presentation he had been diagnosed with a locally advanced unresectable moderately differentiated adenocarcinoma of the GOJ. The patient had been treated initially with chemotherapy consisting of epirubicin, oxaliplatin and 5-fluorouracil for 6 months but on disease progression had been switched to secondline chemotherapy consisting of Paclitaxel. At the time of developing his visual symptoms he had been off chemotherapy for 8 months.

In view of his symptoms and clinical signs he had an MRI orbits with gadolinium contrast. Axial and coronal T1 and short tau inversion recovery (STIR) images through the orbits were obtained. The MRI demonstrated nodular enlargement of bilateral multiple extraocular muscles with isointensity on T1-weighted images (figure 1) and intermediate-to-high signal intensity on T2-weighted images, and showed significant heterogeneous contrast enhancement with gadolinium (figure 2). These changes involved the inferior rectus on the right, bilateral medial recti muscles

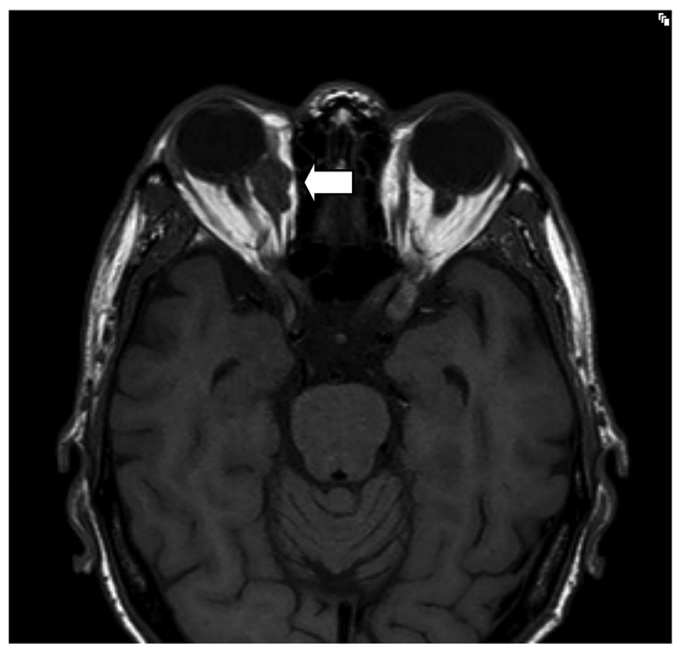

Figure 1 MRI axial T1-weighted images precontrast through the orbits demonstrating enlargement of the right medial rectus muscle.

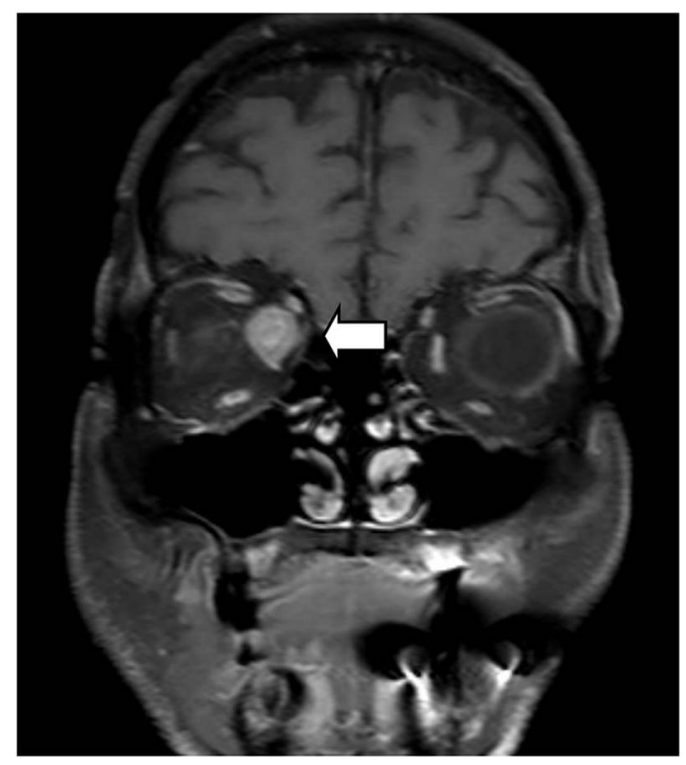

Figure 2 MRI coronal T1-weighted images with fat saturation and postcontrast with intravenous gadolium demonstrating enhancement of the metastasis within the right medial rectus.

and the left superior rectus with the largest lesion involving the right medial rectus.

The patient was admitted from clinic for symptom control, was treated with high-dose

\section{Learning points}

Multiple extraocular muscle involvement by gastro-oesophageal carcinoma metastases is very rare but should be considered in the differential diagnosis for patients presenting with oculomotor symptoms. ${ }^{1}$ It is associated with an extremely poor prognosis. ${ }^{2}$

- The differential diagnosis for extraocular muscles (EOM) metastasis includes thyroid-related orbitopathy and idiopathic orbital myositis which can also result in EOM enlargement.

- The superior contrast resolution provided by MRI of the orbits with contrast enables accurate examination of the orbital structures and anterior visual pathway in a patient presenting with unusual visual symptoms. It detects and characterises lesions of the extraocular musculature accurately and helps to narrow the differential diagnosis. 
steroids and completed a course of palliative radiotherapy. Although he had some symptomatic improvement he died 3 months after this presentation.

Acknowledgements The authors would like to thank Dr Astrid Mayer and Dr Grant Stewart who were consultants involved in caring for this patient.

Contributors All authors contributed equally to this manuscript. MM provided the expert radiological input. MJ wrote and helped edit the initial draft. RG selected the case and edited and prepared the final manuscript.

Competing interests None.
Patient consent Obtained.

Provenance and peer review Not commissioned; externally peer reviewed.

\section{REFERENCES}

1 Ferry AP, Font RL. Carcinoma metastatic to the eye and orbit. A clinicopathologic study of 227 cases. Arch Ophthalmol 1974;92:276-86.

2 Lekse JM, Zhang J, Mawn LA. Metastatic gastrooesophageal junction adenocarcinoma to the extraocular muscles. Ophthalmology 2003;110:318-21.

Copyright 2014 BMJ Publishing Group. All rights reserved. For permission to reuse any of this content visit http://group.bmj.com/group/rights-licensing/permissions.

BMJ Case Report Fellows may re-use this article for personal use and teaching without any further permission.

Become a Fellow of BMJ Case Reports today and you can:

- Submit as many cases as you like

- Enjoy fast sympathetic peer review and rapid publication of accepted articles

- Access all the published articles

- Re-use any of the published material for personal use and teaching without further permission

For information on Institutional Fellowships contact consortiasales@bmjgroup.com

Visit casereports.bmj.com for more articles like this and to become a Fellow 